\title{
THE MILWAUKEE SCHOOL OF TRADES
}

\author{
By Charles F. Perry, S.B., M.E., \\ Director.
}

To trace the existence of the Milwaukee School of Trades, from its present position as part of a public school system, sustained by municipal funds, to its source, is to study the same means which has led to the introduction of kindergarten and manual training schools in our public instructional systems the country over-namely, private, philanthropic initiative.

This school owes its existence to the foresight and initiative of Frederick W. Sivyer, president of the Northwestern Malleable Iron Company. He had always evinced a keen interest in the education of the youth of his native city. For seven years he was a member of the Milwaukee board of school directors and during much of that time was chairman of the manual training committee. On the evening of February 2, 1904, during his inaugural address as president of the Merchants and Manufacturers Association he presented to that body the need of industrial education for the youth of the community and asked for their earnest consideration of the problem.

His request met with an immediate and hearty response. A committee was appointed to gather data regarding trade schools here and abroad. Loyal support was pledged to the movement. In the fall of 1905 part of the original premises of the Pawling and Harnischfeger Company, manufacturers of traveling cranes, was rented, and on January 2, 1906, the doors of the Milwaukee School of Trades were opened to sixty young men eager to become skilled workmen. At first, instruction in but two trades was given, namely, pattern-making and plumbing in the day and night classes. In September of the same year the machinist trade was added to the curriculum.

Early in the year 1907 a problem, which gradually had been growing more and more serious, had to be fairly met and solved. It was a question of finances. To charge students the cost of their tuition in a properly conducted trade school means to debar the very 
ones who need the instruction. Equally impractical is it to expect a few to bear the expense of a work so valuable to the entire community. The need of such a school was proven the first day it opened its doors. From its outset it was making better workmen and better citizens. It was the opportunity and privilege of the Merchants and Manufacturers Association to start such a work in the life of a city, but it was not its bounden duty to continue it. The child grew beyond the power of its parent to support it. Since the work brought a rich harvest to the municipality, the municipality should bear the expense of the sowing. The solution of the problem lay in having the trade school included in the public school system of the city. To do this, a tax, additional to the one already levied for the public schools, was necessary. This extra assessment could be collected only by the permission of the state legislature. Consequently, a bill was prepared and presented to that body early in 1907. It met with immediate endorsement in both assembly and senate. It passed and became effective July I, 1907. There has been such a demand upon the state librarian for copies of this act that all the official copies for distribution have been exhausted. A copy is printed at end of this paper.

The Milwaukee board of school directors immediately seized its opportunity to take over a trade school well equipped to teach three trades and with one and one-half years' experience in pioneer work. On account of this progressive step on the part of the public school authorities the original subscribers deeded the entire equipment of the school to the city in fee simple.

The passage of the act made two vitally necessary things possible, namely, a longer and more thorough course, and free tuition. More floor space was rented and preparations made to include another trade in the curricultum, namely, a thorough course in woodworking. Instruction in this new department began July ist of the present year. This is a brief history of the school up to the present writing. A concise description of our present equipment and policy follows.

Instruction is given in day classes in four trades: Pattern-making, machinist, and wood-working, requiring two years of fifty-two weeks per year, and the plumbing trade, which requires one year. The working hours are from 8.00 to $12.00 \mathrm{a}$. m., and 1.00 to 5.00 p. m., each day of the week excepting Saturday afternoon. Allow- 
ing seven legal holidays per year, the total apprenticeship term in the first three trades is 4,464 hours, and in the plumbing trade 2,232 hours. Night classes are in session from October Ist to April 3oth yearly, from 7.30 to 9.30 o'clock. Each student attends four evenings per week. Tuition is free in the day and evening classes to all young men of Milwaukee between sixteen and twenty years of age who meet the entrance requirements. To all nonresidents, or residents over twenty years of age, a charge of fifteen dollars per month in the day, and four dollars per month in the night classes is made. This charge is slightly under the actual cost to the taxpayer for each student. For all students receiving free tuition a charge of four dollars per month in the day, and one dollar per month in the night classes is made for the material used. This also is slightly under the cost to the taxpayer.

In order to receive free tuition a student must be over sixteen and under twenty years of age. He must be able to read and write in English and perform the fundamental processes in arithmetic. He must also show a marked aptitude for his chosen trade. Graduates of the eighth grade, or students capable of passing examinations equal to those of that grade, are given the preference for admission. The work of the students comes under five separate heads: Trade instruction, mechanical drawing, workshop mathematics, lectures and illustrated talks on subjects pertaining and allied to the trade, including practical physics, chemistry, metallurgy, electricity, etc., and shop inspection trips. Approximately three-fourths of a student's entire apprenticeship is devoted to actual trade practice, the rest of his time is required for the four remaining subjects which are all vitally essential to the intelligent mechanic.

Each trade is equipped for twenty-five students excepting the machine shop which has a capacity of forty. Thus, the total capacity of the school is two hundred thirty students, divided into one hundred fifteen each in day and night classes. The equipment in all departments is of the highest possible grade. The machine shop contains twenty engine lathes, two universal milling machines, two universal grinders, two shapers, three drilling machines, one die slotter, one automatic spur and bevel gear cutter, one speed lathe, fourteen vises, a tempering outfit, and full equipment of standard small tools. The pattern-making and woodworking trades are equipped with twenty-five benches each. Each 
bench is supplied with a separate and complete set of tools in order to prevent conflict between day and night students. The machinery in the pattern shop consists of a universal circular saw, band saw, jointer, planer, large gap lathe, five small lathes, band saw setting and filing machine, and grindstone. The machinery of the woodworking department consists of universal circular saw, band saw, jointer, planer, shaper, molder, tenoner, horizontal borer, jig saw, knife grinder, large lathe, mortiser, four small lathes, bench grinder, and grindstone. The plumbing shop is thoroughly equipped with separate departments for day and night classes.

The entire atmosphere of the school is made as nearly like that of actual commercial manufacturing life as possible. Promptness, close attention to work, and the highest possible standard of workmanship are insisted upon. The moral atmosphere of the school is carefully guarded. Tobacco is not permitted to be used in any form on the premises. Each boy is a class by himself. A diploma of graduation is given each student completing the course in a satisfactory manner, even though he finishes it in less than the prescribed time. He is taught to realize that the grade he receives for his work corresponds with the pay the completed task would bring him as a journeyman. His marks are based, first, upon quality of workmanship; second, time required to do the work; third, his attitude and application to his duties.

The most urgent problem confronting the board of school directors of this city at present, in its industrial education, is what to do with the boy between graduation from the grammar school and his admission to the trade school at the age of sixteen. The state law making it necessary for the boy to be sixteen years of age before being permitted to enter the trade school is an excellent one, providing the public school system furnishes a plan which will make every boy, who wishes to become a skilled artisan, willing to wait until sixteen to enter the trade school. A suggested solution is as follows: To introduce a trade school preparatory course into each one of the four high schools of the city, each one of which is already excellently equipped to teach manual training. This course might properly include shop work, mathematics, and required reading on industrial and commercial subjects from which further practice in English may be had. Thus, this hitherto unspanned gap may be filled with comparatively small cost to the city. 
The future of industrial education in Milwaukee is bright. The Merchants and Manufacturers Association builded better than it knew when it set its hand to the task. The public school authorities are giving the entire problem most loyal support. It is hoped that the work may be extended so that the girls of Milwaukee may also be able to obtain the advantages of vocational training.

\section{APPENDIX}

[No. $75, \mathrm{~S}$.

\section{CHAPTER ..., LAWS OF 1907.}

AN ACT to create sections $926-22$ to $926-30$, inclusive, statutes, providing for the establishment and maintenance of trade schools in the State of Wisconsin.

The people of the State of Wisconsin, represented in Senate and Assembly, do enact as follows:

Section I. There are added to the statutes nine new sections to read: Section 926-22. Any city in the State of Wisconsin or any school district having within its limits a city desiring to establish, conduct and maintain a school or schools for the purpose of giving practical instruction in the useful trades to persons having attained the age of sixteen years, as a part of the public school system of such city, is empowered to do so by complying with the provisions of sections $926-23$ to $926-30$, inclusive, statutes of 1898 .

926-23. Such trade school or schools shall be under the supervision and control of the school boards of the respective cities or school districts in which they may be located.

926-24. The school board of every such city or school district is given full power and authority to establish, take over and maintain a trade school or schools, equip the same with proper machinery and tools, employ a competent instructor or instructors, and give practical instruction in one or more of the common trades. Such a trade school shall not be maintained, however, unless there be an average enrollment of at least thirty scholars.

926-25. Whenever any school board shall have established or taken over an established trade school, such school board may prepare the courses of study, employ instructors, purchase all machinery, tools and supplies, purchase or lease suitable grounds or buildings for the use of such school and exercise the same authority over such school which it now has over the schools under its charge.

926-26. Whenever any school board shall have established or taken over an already established trade school or schools it may appoint an advisory committee, to be known as the committee on trade schools, consisting of five citizens, not members of the school board, each of whom is experienced in one or more of the trades to be taught in the school or schools, to assist in the administration of the trade school or schools located in that city, which com- 
mittee shall be appointed by the president of such school board with the approval of a majority of the board. Stch committee shall have authority, subject to the approval and ratification of the school board, to prepare courses of study, employ or dismiss instructors, purchase machinery, tools and supplies, and purchase or rent suitable grounds or buildings for the use of such trade schools. When any such committee on trade schools is appointed two of its original members shall be appointed for the term of one year, another two for the term of two years, and the fifth member for a term of three years, and thereafter, each member of said committee shall be appointed for the term of two years. In case of any vacancy diring the term of any member of said committee, said school board shall fill such vacancy by appointment for such unexpired term.

926-27. Students attending any such trade school may be required to pay for all material consumed by them in their work in such school at cost prices or in lieu thereof the school board may establish a fixed sum to be paid by each student in each course which sum shall be sufficient to cover, as nearly as may be, the cost of the material to be consumed in such course; any manufactured articles made in such school may be disposed of at the discretion of the school board, and the proceeds shall be paid into the trade school fund.

926-28. Whenever any such school board shall have decided to establish a trade school or schools, or to take over one already established, under the provisions of this act, a tax, not exceeding one-half of one mill on the total assessed valuation of such city shall be levied upon the requisition of the school board, as other school taxes are levied in such city; the fund derived from such taxation shall be known as the trade school fund, shall be used in establishing and maintaining a trade school or trade schools in such city, shall not be diverted or used for any other purpose whatsoever, and may be disposed of and disbursed by the school board of such city in the same manner and pursuant to the same regulations governing the disposition and disbursement of regular school funds by such boards.

926-29. Any school board desiring to avail itself of the provisions of this act, may, before the trade school fund herein provided for becomes available, establish, take over, equip and maintain a trade school or schools out of the regular school funds which may be at the disposal of such school board, provided, however, that all moneys used for these purposes out of the regular school funds shall be refunded within three years from the trade school fund.

926-30. I. When the school board of any city of the second, third or fourth class, or the school board of any school district having within its limits such a city, shall determine to establish, take over, conduct or maintain such trade school, it shall publish notice of its intention so to do with a copy of the resolution or order expressing such determination once each week for four successive weeks in a newspaper published in said school district and shall take no further steps in said matter until the expiration of thirty days from the date of the first publication.

2. If within such thirty days there shall be filed with the clerk of such city a petition signed by a number of electors of the school district equal to twenty per centum of the number of votes cast in said city at the last 
municipal election praying that the question of the establishment, taking over, conduct and maintenance of such trade school shall be submitted to the vote of the electors of such school district, the city clerk shall at the earliest opportunity lay such petition before the common council. The common council shall thereupon at its next regular meeting by resolution or ordinance direct the city clerk to call a special election for the purpose of submitting such question to the electors of such city and school district:

3. Such election shall be noticed and conducted and canvassed in accordance with the provisions of section 943, statutes of 1898 . All electors within the territory constituting such school district, qualified to vote at any election pertaining to school district matters shall be entitled to vote.

4. If any of said school districts shall be beyond the limits of such city, the city clerk shall immediately upon the passage of the resolution or ordinance by the city council ordering such election, transmit a copy thereof to the clerk of the town or towns of which such territory is constituted. The clerk or clerks of said towns shall thereupon cause a notice of such election to be given and such election to be held and canvassed as provided in section 943 .

5. If a majority of the ballots cast in such school district shall be in favor of the establishment, taking over, conducting or maintenance of such trade school, then such board shall proceed as heretofore provided to establish, take over, conduct and maintain such trade school. But if a majority shall vote against such proposition to establish, take over, conduct and maintain a trade school, the board shall take no further steps towards such end.

6. If no petition to submit such proposition to establish, take over or maintain a trade school to the vote of the electors shall be filed with the city clerk within thirty days after the first publication of the notice of the determination of the school board to take such action, then such school board may proceed as hereinbefore provided without submitting such proposition to the electors of the district.

President of the Senate.

Speaker of the Assembly.

This act originated in the Senate.

Chief Clerk. 